\title{
Giuliano Vigini, Charles Péguy
}

\section{Emanuele Kanceff}

\section{Q OpenEdition}

\section{Journals}

\section{Edizione digitale}

URL: https://journals.openedition.org/studifrancesi/41106

DOI: 10.4000/studifrancesi.41106

ISSN: 2421-5856

\section{Editore}

Rosenberg \& Sellier

\section{Edizione cartacea}

Data di pubblicazione: 1 juillet 2004

Paginazione: 218

ISSN: 0039-2944

\section{Notizia bibliografica digitale}

Emanuele Kanceff, «Giuliano Vigini, Charles Péguy», Studi Francesi [Online], 142 (XLVIII | I) | 2004, online dal 30 novembre 2015, consultato il 09 septembre 2021. URL: http://journals.openedition.org/ studifrancesi/41106 ; DOI: https://doi.org/10.4000/studifrancesi.41106

\section{Questo documento è stato generato automaticamente il 9 septembre 2021.}

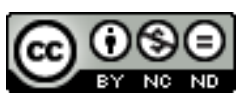

Studi Francesi è distribuita con Licenza Creative Commons Attribuzione - Non commerciale - Non opere derivate 4.0 Internazionale. 


\section{Giuliano Vigini, Charles Péguy}

\section{Emanuele Kanceff}

\section{NOTIZIA}

GiUliano vigini, Charles Péguy, invito alla lettura, Cinisello Balsamo, Edizioni San Paolo, 2003, pp. 96 («Scrittori di Dio, Contemporanei», 90. Collana pubblicata d'intesa con il Progetto culturale promosso dalla Chiesa italiana).

1 Un libretto cristallino e luminoso, com'è nello stile di Giuliano Vigini. Alle puntuali introduzioni segue un'antologia di testi, tratti dai Mystères e da Ève, non essendo possibile abbracciare nel limitato volume altri aspetti dell'opera di Péguy. Le traduzioni sono di Giuliano Vigini, che nel suo fine lavoro ha fatto l'impossibile per rispettare la metrica, la rima e soprattutto la poesia dei testi originali. 